\title{
The Effects of N-Acetylcysteine on MMP-2 and MMP-9 Immune Activities in Testicular Tissue of Streptezotocin Induced Diabetic Rats
}

\author{
N-Asetilsistein'in Streptozotosin İle Oluşturulan Diyabetik Ratların Testis \\ Dokusundaki MMP-2 ve MMP-9 İmmun Aktivitelerine Etkileri
}

\author{
Alper Yalçın \\ Adiyaman University, Faculty of Medicine, Department of Histology and Embriyology, Adiyaman-TURKEY \\ Yazıșma Adresi / Correspondence: \\ Alper Yalcin \\ Adiyaman University, Faculty of Medicine Department of Histology and Embriology, Adiyaman-TURKEY \\ T: +904162231690 E-mail: alperyalcin0171@hotmail.com \\ Geliş Tarihi / Received : 06.12.2018 Kabul Tarihi / Accepted : 28.02.2019
}

\footnotetext{
Abstract

Objective This study was performed to investigate the effects of N-Acetylcysteine (NAC) on matrix metalloproteinases (Mmp-2 and Mmp-9) immunoreactivity in testicular tissue of diabetic rats. ( Sakarya Med J 2019, 9(1):59-67)

Materials 28 male rats were allocated into four groups n (7); No treatment was applied to control group. Animals in the NAC alone group was treated with i.p.100 mg/kg NAC daily. and Methods Diabetes was induced upon injection of a single dose streptozocin $50 \mathrm{mg} / \mathrm{kg}$ intraperitoneally on diabetes group (DM). Following diabetes development, Diabetic $+\mathrm{NAC}$ groups were treated with i.p. $100 \mathrm{mg} / \mathrm{kg}$ NAC daily. Oxidative damage was evaluated with Total Antioxidant Status (TAS) and Total Oxidant Status (TOS) activities while the testicular damage was determined by histopathological evaluation and immunohistochemical assessment of MMP-2 and MMP-9 at the testicular tissues.

Results TAS levels were found to be increased in diabetic NAC-treated group animals whereas TOS, MMP-2 and MMP-9 levels were decreased in the same group. For the histological findings, there were no testicular changes in the NAC alone and control group whereas the alterations such as marked degeneration, vacuole formation and basement membrane thickening of tubules seminiferus contortus were observed in the testicular tissues of the DM group. But, in the treatment group, DM+NAC, these alterations were found to be comparatively decreased.

Conclusion Our findings suggest that administration of NAC minimize testicular damage in diabetic rats and might be a potential candidate to reduce/eliminate the negative effects of diabetes on the testicular tissue.

Keywords NAC, MMP2, MMP9, Testes, Diabetes

Amac Bu çalısma N-Asetilsisteinnin (NAS), diyabetik ratların testis dokusunda metalloproteinazların (Mmp2-Mmp9) immun reaktivitesi üzerine olan etkilerini arastırmak amaciyla yapıldi. ( Sakarya Tip Dergisi 2019, 9(1):59-67).

Gereçve 28 adet erkek rat 4 gruba ayrldı (n:7). Kontrol grubu hayvanlarnna herhangi bir uygulama yapılmadı. NAS grubundaki hayvanlara 30 günlük deney süresince her gün i.p. 100 mg/kg NAS Yöntemler verildi. Diyabet grubundaki (DM) hayvanlarda diyabeti olusturmak için intaperitonel (i.p.) tek doz $50 \mathrm{mg} / \mathrm{kg}$ streptozotosin uygulandı. Diyabet olusumundan sonra DM + NAS grubuna 27 gün sure ile her gün i.p. $100 \mathrm{mg} / \mathrm{kg}$ NAS verildi. Oksidatif hasar, toplam antioksidan ve toplam oksidan aktivitelerinin ölçümü ile; testis hasart ise testis dokusunun histopatolojisi ve Mmp2-Mmp9 immun reaksiyonlarının immunhistokimyasal değerlendirmesi ile yapıldt.

Bulgular Diyabetik ratlardaki düşük olan TAS seviyesinin, NAS uygulanan diyabetik ratlarda artmış olduğu saptandı. Diyabetik ratlarda artmış olan TOS, Mmp2 ve Mmp9'un NAS uygulaması ile azaldığı gözlendi. NAS uygulanan grupta testis dokusunun olağan histolojik yapısına sahip olduğu gözlendi. Kontrol grubu ile karşılaşttrıldiğında, DM grubunda göze çarpar bir şekilde dejenerasyon, vakuol olușumu ve seminifer tübüllerin bazal membranında kalınlașma gözlendi. DM ile karșılaștırıldığında, DM + NAS grubunda dokudaki hasarın belirgin șekilde azaldı̆̆ı gözlendi.

Sonuc Bulgularımız NAS uygulamasının diyabetik ratlarda testis hasarını azalttı̆̆ııı ve diyabetin testis dokusu üzerindeki negatif etkilerini azaltma/elimine etmekte kullanılabileceğini göstermektedir. 


\section{INTRODUCTION}

$\mathrm{DM}$ is a metabolic condition that causes any deficiency or disability in the mechanism of insulin. ${ }^{1}$ In addition to disruption of the insulin mechanism, there are common disorders in carbohydrate, fat, and protein metabolism ${ }^{2,3}$ and therefore problems in other organs and systems. ${ }^{4-6}$ Male infertility is a serious complication of DM in addition to the other major organ and/or organ systems disorders. ${ }^{6,7}$ Adverse effects of diabetes mellitus on fertility occur at several different ways. ${ }^{8,9}$ Altered spermatogenesis, degenerative and apoptotic testicular changes, inconsistent glucose and testosterone levels, and also insufficient sexual physical behaviors were described both in diabetic men and animal models. ${ }^{10}$

The blood-testes barrier is essential for the development and maturation of germ cells. ${ }^{11}$ MMPs are endopeptidases and may degrade the most proteinous components of the extracellular matrix (ECM) and basement membranes. ${ }^{12}$ MMP-2 (gelatinase A) and MMP-9 (gelatinase B) involved in the functioning of the blood-testes barrier ${ }^{13,14}$ that are secreted by Sertoli and peritubular cells and these two cell types cooperate for deposition of ECM components in the basement membrane. ${ }^{15,16}$

Besides endocrine disorders, ${ }^{17}$ oxidative stress is also an important factor in the pathogenesis of many chronic complications of diabetes. ${ }^{5,18-23}$ Among the targets of oxidative stress in diabetes are MMP-2 and MMP-9, which are susceptible to oxidative stress. ${ }^{24}$ Changes in the blood-testis barrier in streptozotocin-induced diabetic rats adversely affect spermatogenesis. ${ }^{25}$

NAC, a precursor of reduced glutathione (GSH), has been used in therapeutic practices. ${ }^{26}$ Experimental studies suggest that NAC showed increased antioxidant capacity and depression of reactive oxygen species rate associated with increases of GSH levels. ${ }^{27} \mathrm{GSH}$ is the most important intracellular antioxidant. ${ }^{28} \mathrm{NAC}$ showed the ability to prevent the toxic effects of oxidative stress during diabetes and have been proposed as a complementary treatment. ${ }^{29-32}$ The mechanisms responsible for the beneficial effects of NAC have been associated to its antioxidant properties. ${ }^{33-35}$ Antioxidant treatments that relied on the effects of oxidative stress have reduced glycemic index and also complications of DM. ${ }^{36,37}$ Therefore, in this study, whether the contribution of NAC to prevent pathology in the blood-testis barrier, which is known to be damaged in diabetic rats was investigated by immunohistochemical, pathological and biochemical methods.

\section{MATERIALS and METHODS}

\section{Chemicals and Test kits}

Streptozotosin (STZ) (Sigma Chemical Co Louis Missouri), acetylcysteine (NACR, Basel Pharmaceutical Inc. Sakarya-Turkey), Total Oxidant and Antioxidant Status Test Kits (Rel Assay DiagnosticR, Gaziantep, Turkey), and analytical reagents and solvents (Sigma Aldrich ${ }^{\circledR}$ and Merck $^{\circledast}$ ) which used in all procedures were commercially purchased.

\section{Animals, diets and experimental protocols}

A total of 28 male Wistar Albino Rat (200-220 gr), 8-10 weeks of age, supplied by Adıyaman University Experimental Animal Production and Research Center were divided into four groups $(n=7)$. After seven-days acclimatization in a room condition at which maintained $12 \mathrm{~h}$ light/ $12 \mathrm{~h}$ dark cycle at room temperature $\left(25 \pm 3^{\circ} \mathrm{C}\right)$ with ad libitum standard rodent pellet diet and water, the experiment was started. First group was named as Control group and animals were maintained on rodent standard pellet diet and water ad libitum, without any treatment during 30 days of experimental period. The second group was called as DM group. Streptozotocin was dissolved in $0.1 \mathrm{M}$ sodium citrate buffer (pH: 4.5) and a single dose of STZ in $50 \mathrm{mg} / \mathrm{kg}$ ratio was administered to animals via i.p. route at the first day of the experiment. After 72 hours, blood samples were taken from the tail veins. Animals with glucose levels above $250 \mathrm{mg} / \mathrm{dl}$ were considered as diabetic. The third group was called DM+NAC group. Streptozotocin was dissolved 
in $0.1 \mathrm{M}$ sodium citrate buffer ( $\mathrm{pH}$ : 4.5) and a single dose of STZ in $50 \mathrm{mg} / \mathrm{kg}$ ratio was administered to animals via i.p. route. After 72 hours, animals with blood glucose levels above $250 \mathrm{mg} / \mathrm{dl}$ were considered diabetic in samples taken from the tail vein. Following experimental diabetes, NAC was administered daily at a dose of $100 \mathrm{mg} / \mathrm{kg}$ via i.p. route until the end of the experiment. The animals in the fourth group, defined as the NAC group, were administered daily $100 \mathrm{mg} / \mathrm{kg}$ NAC via i.p. route for the duration of the experiment. Glucose levels and body weights of all groups were measured and recorded regularly at the onset and at the end of the experiment. At the end of the experiment, rats in all groups were decapitated under ketamine $(75 \mathrm{mg} / \mathrm{kg})+$ xylazine $(10 \mathrm{mg} / \mathrm{kg})$ anesthesia.

Throughout the experiment, animals were processed according to the suggested ethical guidelines for the care of laboratory animals (Laboratory Animal Care Committee of Adiyaman University, protocol number: 2018/008). Blood samples were collected by cardiac puncture before decapitation under the anesthesia.

\section{Tissue preparation and histopathologic examination}

Animals were sacrificed after collecting the blood samples. Testes tissues were removed and fixed in buffered $10 \%$ formalin solution. Tissue samples were embedded in paraffin after routine procedures and then sectioned and stained with hematoxylin-eosin $(\mathrm{HxE})$ and then stained sections were blindly analyzed by two experts. Mainly marked degeneration, vacuole formation and basement membrane thickening were scanned under a light microscope (Leica DM500 attached Leica DFC295 Digital Image Analyze System).

\section{Immunohistochemical methods:}

Streptavidin-biotin-peroxidase complex method was used with Thermo Scientific ${ }^{\text {Ts }}$ TP-015-HA commercial kit. Antibodies against Matrix Metalloproteinase-2 (MMP-2, Rabbit Polyclonal H-029-30, Phoenix Pharmaceuticals, Inc., California, USA) and Matrix Metalloproteinase-9
(MMP-9, Rabbit Polyclonal, BS-4593R Bioss Inc., Massachusetts) with $1 / 200$ dilutions. Positive and negative controls were made as recommended by the manufacturers. Sections were visualized with 3-amino-9-ethylcarbazole (AEC) chromogens and background colorized with Mayer's Hematoxylin. Sections were scanned under a light microscope (Leica DM500 attached Leica DFC295 Digital Image Analyze System). A histological score was created based on the prevalence of immunopositivity as $0.1:<25 \%$, 0.4:26-50, \%0.6:51-75\%, 0.9:76-100\%) and severity (0: no lesion, +0.5 : very little lesion, +1 : little lesion, +2 : mild lesion, +3: moderate lesion). Histological scorer $=$ Distribution $\mathrm{x}$ severity.

\section{Biochemical analysis:}

After the experimental period, blood samples were taken from animals by intracardiac puncture under general anesthesia and then centrifuged at $2500 \mathrm{rpm}$ to separate sera for 5 minutes. The obtained sera were stored at $-200 \mathrm{C}$ until analyzed. To evaluate the degree of damage, Serum Total Antioxidant Level (TAS), 38 and Total Oxidant Level (TAS), 39 were measured for judging the degree of damage based on previous studies, by using the Total Antioxidant Status Assay Test Kit (Rel Assay DiagnosticR, Gaziantep, Turkey) and the Total Oxidant Status Assay Test Kit (Rel Assay DiagnosticR, Gaziantep, Turkey) with auto analyzer (Olympus AU2700).

\section{Statistical Methods}

Statistical analysis was performed in SPSS 15.0 program. The normal distribution of the TAS, TOS and immune variables in the groups was evaluated by Kolmogorov Smirnov test. One-way variance-analysis was used for TAS, TOS and Immune variables between groups. Levene statistics were used for homogeneity test of variances. Tukey dual comparison test was used to determine the differences of groups of significant variables. Results were given as mean \pm SD. Significance level was accepted at least $\mathrm{P}$ $<0.05$. 


\section{RESULTS}

Beginning and final body weights of animals

When compared the beginning and final body weights of rats in all groups were evaluated; the final body weights of the Control and NAC groups were statistically higher than the beginning $(\mathrm{p}<0.05)$. However, the body weights of DM and DM+NAC groups were statistically decreased compared to the beginning $(\mathrm{p}<0.05)$. (Table 1$)$.

\section{Biochemical Findings}

Blood-glucose levels: The beginning and final blood-glucose levels of the rats in all groups were compared and no changes were observed in the Control and NAC groups. However, blood-glucose levels in DM and DM+NAC groups were found to be significantly increased compared to the beginning $(\mathrm{p}<0.05)$. (Table 2$)$.
TAS and TOS levels: The level of TOS, which was significantly elevated in the DM group ( $\mathrm{p}<0.05$ ), was close to each other in the Control, NAC, and NAC + DM groups ( $p$ $<0.05)$. A significant TAS level decrease was observed in DM group compared to DM + NAC group $(\mathrm{p}<0.05)$ and also in DM+NAC group compared to Control and NAC groups ( $<<0.05)$ (Table. 3$)$.

\section{Histopathological Findings}

In microscopical examination of HE stained sections, normal histological testicular tissues were seen in the Control (Figure 1a) and NAC (Figure 1b) groups. When compared with the Control group, marked degeneration, vacuole formation and basement membrane thickening of tubules seminiferus contortus were observed in the DM group (Figure 1c). Compared with DM group, a marked decrease of

Table 1. Beginning and final body weights of animals (g).

\begin{tabular}{|l|c|c|c|c|}
\hline & Control & NAC & DM & DM+NAC \\
\hline Beginning body weights $(\mathrm{g})$ & $211.96 \pm 14.08$ & $201.02 \pm 15,20$ & $250.73 \pm 11.10$ & $222.05 \pm 15.88$ \\
\hline Final body weights $(\mathrm{g})$ & $268,17 \pm 8.68 \mathrm{a}$ & $284,63 \pm 9,07 \mathrm{a}$ & $179,27 \pm 6,48 \mathrm{a}$ & $178,25 \pm 15,75 \mathrm{a}$ \\
\hline
\end{tabular}

Values are given as mean \pm standard deviation.

a According to the beginning body weight $(\mathrm{p}<0.05)$.

Table 2. Beginning and final blood-glucose levels of animals (mg/dl).

\begin{tabular}{|l|c|c|c|c|}
\hline & Control & NAC & DM & DM+NAC \\
\hline Beginning blood-glucose levels $(\mathrm{mg} / \mathrm{dl})$ & $102,94 \pm 4.31$ & $105,41 \pm 2.45$ & $105.37 \pm 2.24$ & $102.93 \pm 2.13$ \\
\hline Final blood-glucose levels $(\mathrm{mg} / \mathrm{dl})$ & $103.30 \pm 5.06$ & $107,09 \pm 3.78$ & $384.76 \pm 54.43 \mathrm{a}$ & $374.44 \pm 53.77 \mathrm{a}$ \\
\hline $\begin{array}{l}\text { Values are given as mean } \pm \text { standard deviation. } \\
\text { a According to the beginning blood-glucose levels, } \mathrm{p}<0.05) .\end{array}$ \\
\hline
\end{tabular}

\begin{tabular}{l}
\begin{tabular}{l} 
Table 3: Serum TAS and TOS levels and immunohistochemical localizations of MMP-2 and MMP-9 in testes tissues of \\
animals. \\
\hline
\end{tabular}$\quad$ N \\
\hline
\end{tabular}


these lesions were observed in the DM+NAC group ( $\mathrm{Fi}$ gure 1d).

\section{Immunohistochemical Findings}

Immunohistochemical investigations showed that both MMP-2 (Figure 2a-2d) and MMP-9 (Figure 3a-3d) immunoreactivity were especially localized in the seminiferous tubules in the testicular tissue. Granular-type cytoplasmic staining was observed both sertoli and in germ cells.

A significant elevation of both MMP-2 and MMP-9 levels were detected in DM group compared with the Control and NAC groups $(\mathrm{P}<0.05)$. but this value was statistically insignificant. Although no statistically significant difference between DM and DM+NAC groups were observed. $(\mathrm{P}<0.05)$ (Table 3), both MMP-2 and MMP-9 levels were decreased at DM + NAC groups compared to DM.

\section{DISCUSSION}

Arrangement of intercellular junctions and associated proteins are critically important in the movement of germ cells across the seminiferous epithelium in the unique design of spermatogenesis. ${ }^{40}$ Sertoli cells are indispensable in supporting developing germ cells, and any damage to them leads to reduced support capabilities. ${ }^{41,42}$ Because of the deterioration of adhesion between the Sertoli cells and germ cells, the movement of germ cells within the seminiferous epithelium disrupt and early release of immature germ cells occur during differentiating of germ cells moving across the BTB and this is likely to cause infertility. ${ }^{40,43}$

The permeability of BTB is affected by the cytokine-mediated, ${ }^{44}$ and/or by protease-mediated corruption of junction proteins. MMPs, a group of proteases, can disrupt or regulate the different blood barriers (including blood-testes
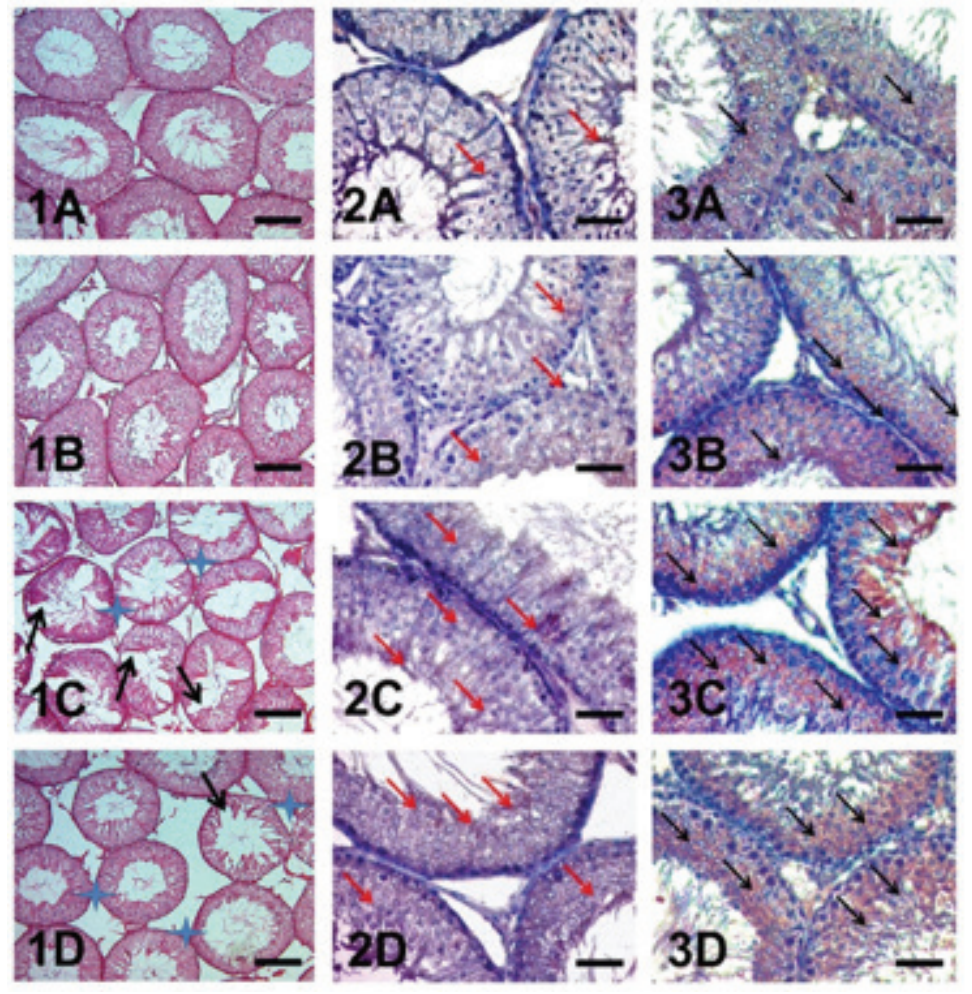

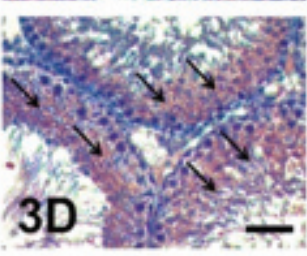

Figure 1A-D: Hematoxylin \& Eosin stained testes. The scale bars represent $100 \mu \mathrm{m}$. A: Microscopical view of Control group. Normal testicular tissues. B: Microscopical view of NAC-treated group. Normal testicular tissue view. C: Microscopical view of DM group. Marked degeneration (black arrow) and basement membrane thickening (blue asterix) of seminiferous tubules were observed in the DM group. D: Microscopical view of DM + NAC. A significant decrease of degeneration (black arrow) and basement membrane thickening (blue asteriks) of seminiferus tubules.

Figure 2A-D: MMP-2 immunoreactivity of testes tissues. The scale bars represent $25 \mu \mathrm{m}$. Tissues were stained with Streptavidin biotin peroxidase complex method with Mayer's Hematoxylin counterstain. AEC chromogen was used for visualization. A: Control group. B: NAC group. C: DM group. D: $\mathrm{DM}+\mathrm{NAC}$ group.

Figure 3A-D: MMP-9 immunoreactivity of testes tissues. The scale bars represent $25 \mu \mathrm{m}$. Tissues were stained with Streptavidin biotin peroxidase complex method with Mayer's Hematoxylin counterstain. AEC chromogen was used for visualization. A: Control group. B: NAC group. C: DM group. D: $\mathrm{DM}+\mathrm{NAC}$ group. 
barrier) by degrading tight junction proteins. ${ }^{45-47}$

Matrix metalloproteinase- 9 is essential for assessing semen quality ${ }^{48}$ and MMP-2 regulates the migration of spermatogonia and spermatocytes. ${ }^{49}$ MMP-2 activation in the testis contributes to the decreased supportive capacity of Sertoli cells by altering junctional connections between Sertoli cells and germ cells $s^{41,50}$ and such disruptions will cause initiating germ cell detachment. ${ }^{41}$ In an in vivo study MMP-2-induced germ cell detachment inhibited by pretreatment with a MMP-2 inhibitor. ${ }^{42}$

Decreases in tissue inhibitor of metalloproteinase-2 (TIMP-2) expression in Sertoli cells led to MMP-2 activation. ${ }^{42}$ Activated MMP-2 may alter the microenvironment in the adluminal compartment and further lead to the remodeling of tight junctions at the BTB between adjacent Sertoli cells. Finally, activated MMP-2 may directly breaks laminin/integrin complexes at apical ectoplasmic specializations (ESs) between Sertoli cells and spermatids and further contribute to the release of these cells into the lumen. ${ }^{41}$

Immunoreactivity of MMP-2 and MMP-9 explained by researchers in mice, ${ }^{51}$ rats $^{52}$ and dogs. ${ }^{48}$ MMP-2 has been reported to be localized in apical ESs that are mainly associated with the heads of prolonged spermatids. ${ }^{52}$ In dogs, MMP-2 immunoreactivity was described in head of elongate spermatid, residual body and the Sertoli cell and MMP-9 immunoreactivity was defined in cytoplasm of spermatocyte, round spermatid and residual body. ${ }^{48}$ Same to researchers intra- or extra tubular immunoreactivity were detected testes tissues of rats in immunohistochemical staining. These more frequently cytoplasmic immunopositivity were seen more intense in diabetic animals. Although they did not decrease to the extent of the control levels, these values were significantly decreased in NAC-treated diabetic animals.

According to the results obtained in the study, the high
MMP-2 and MMP-9 levels in diabetic animals are not compatible with the results of some studies, but there is no discrepancy. Because, in experimental and in field studies in which MMP levels are detected, especially in diabetics, differences are observed in serum and tissue levels, in different tissues, in active and passive form, and in the method used to determine. For example, significantly elevated MMP-9 was measured in the sera of diabetic patient 53 and increased levels of activated MMP-2 and MMP-9 from the retinas of diabetic patients had been reported. ${ }^{4}$ A significant reduce was described the activity of latent MMP-2, active MMP-2 and MMP-9 in diabetic testes by using different techniques and decreases in MMP-2 and MMP-9 have been associated with testopathy. ${ }^{54}$ When the literature on the subject is viewed collectively, the detrimental effects of both increases and decreases of MMPs levels are damaging for the total health of the organism. Therefore, the steady-state balance levels are essential for leading a healthy life.

Oxidative stress associated testicular damages has been described both in diabetic rats and humans. Testicular oxidative stress, induced by both oxygen and nitrogen free radicals, cause MMPs activation and this irregular MMPs and TIMPs are adversely affect the construction of the multi-layered epithelium and cytoskeleton of germ cells. ${ }^{24,55,56}$ In our study, elevated TOS and decreased TAS levels in diabetic animals returned to normal course with NAC treatment. In parallel with the increase of oxidative stress, MMP-2 and MMP-9 levels were high in the diabetic animals and these levels decreased with NAC administration. TAS levels increased with NAC administration, whereas MMP-2 and MMP-9 immunoreactivities decreased.

In conclusion; in our study, it was observed that the evident decrease in body weights of diabetic animals were not prevented by NAC treatments and similarly increased blood glucose levels in diabetic animals were not affected by NAC applications. But, NAC application caused a decrease in elevated MMP-2 and MMP-9 levels which elevated with diabetes. These findings suggest that NAC might be a po- 
tential candidate to reduce/eliminate the negative effects

of diabetes especially on male fertility on the testes health.

\section{Acknowledgements}

The author declares that they have no conflict of interest. 


\section{Sakarya Med J 2019;9(1):59-67}

\section{References}

1. Agbaje IM, Rogers DA, McVicar CM, McClure N, Atkinson AB, Mallidis C, et al. Insulin dependant diabetes mellitus: implications for male reproductive function. Hum Reprod Oxf Engl 2007;22:1871-1877.

2. Hasselbaink DM, Glatz JFC, Luiken JJFP, Roemen THM, Van der Vusse GJ. Ketone bodies disturb fatty acid handling in isolated cardiomyocytes derived from control and diabetic rats. Biochem J 2003;371:753-760.

3. Jeejeebhoy KN, Chu RC, Marliss EB, Greenberg GR, Bruce-Robertson A. Chromium deficiency, glucose intolerance, and neuropathy reversed by chromium supplementation, in a patient receiving long-term total parenteral nutrition. Am J Clin Nutr 1977;30:531-538.

4. Das A, McGuire PG, Eriqat C, Ober RR, DeJuan E, Williams GA, et al. Human diabetic neovascular membranes contain high levels of urokinase and metalloproteinase enzymes. Invest Ophthalmol Vis Sci 1999;40:809-813.

5. Mallidis C, Agbaje IM, Rogers DA, Glenn JV, Pringle R, Atkinson AB, et al. Advanced glycation end products accumulate in the reproductive tract of men with diabetes. Int J Androl 2009;32:295-305.

6. Melendez-Ramirez LY, Richards RJ, Cefalu WT. Complications of type 1 diabetes. Endocrinol Metab Clin North Am 2010;39:625-640.

7. Atkinson MA, Maclaren NK. The pathogenesis of insulin-dependent diabetes mellitus. $N$ Engl J Med 1994;331:1428-1436.

8. Ficher M, Zuckerman M, Fishkin RE, Goldman A, Neeb M, Fink PJ, et al. Do endocrines play an etiological role in diabetic and nondiabetic sexual dysfunctions? J Androl 1984;5:816.

9. Steger $R W$, Rabe MB. The effect of diabetes mellitus on endocrine and reproductive function. Proc Soc Exp Biol Med Soc Exp Biol Med N Y N 1997;214:1-11.

10. Jangir RN, Jain GC. Diabetes mellitus induced impairment of male reproductive functions: a review. Curr Diabetes Rev 2014;10:147-157.

11. Mital P, Hinton BT, Dufour JM. The blood-testis and blood-epididymis barriers are more than just their tight junctions. Biol Reprod 2011;84:851-858.

12. Vu TH, Werb Z. Matrix metalloproteinases: effectors of development and normal physiology. Genes Dev 2000;14:2123-2133.

13. Longin J, Le Magueresse-Battistoni B. Evidence that MMP-2 and TIMP-2 are at play in the FSH-induced changes in Sertoli cells. Mol Cell Endocrinol 2002;189:25-35.

14. Siu MKY, Lee WM, Cheng CY. The interplay of collagen IV, tumor necrosis factor-alpha, gelatinase B (matrix metalloprotease-9), and tissue inhibitor of metalloproteases-1 in the basal lamina regulates Sertoli cell-tight junction dynamics in the rat testis. Endocrinology 2003; 144:371-387.

15. Fritz IB, Tung M, Ailenberg M. Proteases and antiproteases in the seminiferous tubules. In: Russell LD, Griswold MD (eds.). The Sertoli Cell. Clearwater, FL: Cache River Press, 1993. p.217-235.

16. Skinner MK. Cell-cell interactions in the testis. Endocr Rev 1991;12:45-77.

17. La Vignera S, Condorelli R, Vicari E, D'Agata R, Calogero AE. Diabetes mellitus and sperm parameters. J Androl 2012;33:145-153.

18. Amaral S, Oliveira PJ, Ramalho-Santos J. Diabetes and the impairment of reproductive function: possible role of mitochondria and reactive oxygen species. Curr Diabetes Rev 2008;4:46-54.

19. Giugliano D, Ceriello A, Paolisso G. Oxidative stress and diabetic vascular complications. Diabetes Care 1996;19:257-267.

20. Karimi J, Goodarzi MT, Tavilani H, Khodadadi I, Amiri I. Relationship between advanced glycation end products and increased lipid peroxidation in semen of diabetic men. Diabetes Res Clin Pract 2011;91:61-66.

21. Nishikawa T, Edelstein D, Brownlee M. The missing link: a single unifying mechanism for diabetic complications. Kidney Int Suppl 2000;77:S26-30.

22. Piconi L, Quagliaro L, Ceriello A. Oxidative stress in diabetes. Clin Chem Lab Med 2003;41:1144-1149.

23. Wiernsperger NF. Oxidative stress as a therapeutic target in diabetes: revisiting the controversy. Diabetes Metab 2003;29:579-585.

24. Visse R, Nagase H. Matrix metalloproteinases and tissue inhibitors of metalloproteinases: structure, function, and biochemistry. Circ Res 2003;92:827-839.

25. Alves MG, Martins AD, Cavaco JE, Socorro S, Oliveira PF. Diabetes, insulin-mediated glucose metabolism and Sertoli/blood-testis barrier function. Tissue Barriers 2013;1:e23992.

26. Hurst GA, Shaw PB, LeMaistre CA. Laboratory and clinical evaluation of the mucolytic properties of acetylcysteine. Am Rev Respir Dis 1967;96:962-970.

27. Gibson KR, Neilson IL, Barrett F, Winterburn TJ, Sharma S, MacRury SM, et al. Evaluation of the Antioxidant Properties of N-acetylcysteine in Human Platelets: Prerequisite for
Bioconversion to Glutathione for Antioxidant and Antiplatelet Activity: J Cardiovasc Pharmacol 2009;54:319-326.

28. Witschi A, Reddy S, Stofer B, Lauterburg BH. The systemic availability of oral glutathione. Eur J Clin Pharmacol 1992;43:667-669.

29. Ho E, Chen G, Bray TM. Supplementation of $N$-acetylcysteine inhibits NFאB activation and protects against alloxan-induced diabetes in CD-1 mice. FASEB J 1999;13:1845-1854.

30. Kaneto H, Kajimoto Y, Miyagawa J, Matsuoka T, Fujitani Y, Umayahara Y, et al. Beneficial effects of antioxidants in diabetes: possible protection of pancreatic beta-cells against glucose toxicity. Diabetes 1999;48:2398-2406.

31. Masha A, Brocato L, Dinatale S, Mascia C, Biasi F, Martina V. N-acetylcysteine is able to reduce the oxidation status and the endothelial activation after a high-glucose content meal in patients with Type 2 diabetes mellitus. J Endocrinol Invest 2009;32:352-356.

32. Xia Z, Liu M, Wu Y, Sharma V, Luo T, Ouyang J, et al. N-acetylcysteine attenuates TNF- $\alpha$-induced human vascular endothelial cell apoptosis and restores eNOS expression. Eur J Pharmacol 2006;550:134-142.

33. Rigotti A, Miettinen HE, Krieger M. The role of the high-density lipoprotein receptor SR-BI in the lipid metabolism of endocrine and other tissues. Endocr Rev 2003;24:357-387.

34. Rushworth GF, Megson IL. Existing and potential therapeutic uses for N-acetylcysteine: The need for conversion to intracellular glutathione for antioxidant benefits. Pharmacol Ther 2014;141:150-159.

35. Samuni Y, Goldstein S, Dean OM, Berk M. The chemistry and biological activities of $N-a$ cetylcysteine. Biochim Biophys Acta 1830;2013:4117-4129.

36. Mohasseb M, Ebied S, Yehia MAH, Hussein N. Testicular oxidative damage and role of combined antioxidant supplementation in experimental diabetic rats. J Physiol Biochem 2011;67:185-194.

37. Rahimi R, Nikfar S, Larijani B, Abdollahi M. A review on the role of antioxidants in the management of diabetes and its complications. Biomed Pharmacother Biomedecine Pharmacother 2005; 59:365-373.

38. Erel $O$. A novel automated direct measurement method for total antioxidant capacity using a new generation, more stable ABTS radical cation. Clin Biochem 2004;37:277-285.

39. Erel O. A new automated colorimetric method for measuring total oxidant status. Clin Biochem 2005;38:1103-1111.

40. Russell LD, Peterson RN. Sertoli cell junctions: morphological and functional correlates. Int Rev Cytol 1985;94:177-211.

41. Yao P-L, Lin Y-C, Richburg JH. Mono-(2-ethylhexyl) phthalate-induced disruption of junctional complexes in the seminiferous epithelium of the rodent testis is mediated by MMP2. Biol Reprod 2010;82:516-527.

42. Yao P-L, Lin Y-C, Richburg JH. TNF alpha-mediated disruption of spermatogenesis in response to Sertoli cell injury in rodents is partially regulated by MMP2. Biol Reprod 2009;80:581-589.

43. Gray KJ, Engelmann UH, Johnson EH, Fishman IJ. Evaluation of misoprostol cytoprotection of the bladder with cyclophosphamide (Cytoxan) therapy. J Urol 1986;136:497-500.

44. Lui W-Y, Lee WM. Molecular mechanisms by which hormones and cytokines regulate cell junction dynamics in the testis. J Mol Endocrinol 2009;43:43-51.

45. Navaratna D, McGuire PG, Menicucci G, Das A. Proteolytic degradation of VE-cadherin alters the blood-retinal barrier in diabetes. Diabetes 2007;56:2380-2387.

46. Reijerkerk A, Kooij G, van der Pol SMA, Khazen S, Dijkstra CD, de Vries HE. Diapedesis of monocytes is associated with MMP-mediated occludin disappearance in brain endothelial cells. FASEB J Off Publ Fed Am Soc Exp Biol 2006;20:2550-2552.

47. 47. Yang Y, Estrada EY, Thompson JF, Liu W, Rosenberg GA. Matrix metalloproteinase-mediated disruption of tight junction proteins in cerebral vessels is reversed by synthetic matrix metalloproteinase inhibitor in focal ischemia in rat. J Cereb Blood Flow Metab Off J Int Soc Cereb Blood Flow Metab 2007;27:697-709.

48. Warinrak C, Wu J-T, Hsu W-L, Liao J-W, Chang S-C, Cheng F-P. Expression of matrix metalloproteinases (MMP-2, MMP-9) and their inhibitors (TIMP-1, TIMP-2) in canine testis, epididymis and semen. Reprod Domest Anim Zuchthyg 2015;50:48-57.

49. Longin J, Guillaumot P, Chauvin MA, Morera AM, Le Magueresse-Battistoni B. MT1-MMP in rat testicular development and the control of Sertoli cell proMMP-2 activation. J Cell Sci 2001;114:2125-2134

50. Chen H, Lam Fok K, Jiang X, Chan HC. New insights into germ cell migration and survival/apoptosis in spermatogenesis: Lessons from CD147. Spermatogenesis 2012;2:264-272.

51. Barone R, Pitruzzella A, Marino Gammazza A, Rappa F, Salerno M, Barone F, et al. Nandrolone decanoate interferes with testosterone biosynthesis altering blood-testis barrier components. J Cell Mol Med 2017;21:1636-1647. 
Sakarya Med J 2019;9(1):59-67

52. Siu MKY, Cheng CY. Interactions of proteases, protease inhibitors, and the betal integrin/ laminin gamma 3 protein complex in the regulation of ectoplasmic specialization dynamics in the rat testis. Biol Reprod 2004;70:945-964.

53. Maxwell PR, Timms PM, Chandran S, Gordon D. Peripheral blood level alterations of TIMP-1, MMP-2 and MMP-9 in patients with type 1 diabetes. Diabet Med J Br Diabet Assoc 2001;18:777-780.

54. Zhang Q, Liu H-R, Ying H-J, Dai D-Z, Tang X-Y, Dai Y. Strontium fructose 1,6-diphosphate alleviates early diabetic testopathy by suppressing abnormal testicular matrix metalloproteinase system in streptozocin-treated rats. J Pharm Pharmacol 2009;61:229-236.
55. Mallidis C, Agbaje I, Rogers D, Glenn J, McCullough S, Atkinson AB, et al. Distribution of the receptor for advanced glycation end products in the human male reproductive tract: prevalence in men with diabetes mellitus. Hum Reprod Oxf Engl 2007;22:2169-2177.

56. Tang X-Y, Zhang Q, Dai D-Z, Ying H-J, Wang Q-J, Dai Y. Effects of strontium fructose 1,6-diphosphate on expression of apoptosis-related genes and oxidative stress in testes of diabetic rats. Int J Urol Off J Jpn Urol Assoc 2008;15:251-256. 